\title{
Field-based assessment of rock discontinuity and geological attributes of rock mass for stones for various engineering applications
}

\author{
*Sunita Bhattarai ${ }^{1}$ and Naresh Kazi Tamrakar ${ }^{2}$ \\ ${ }^{1}$ Department of Mines and Geology, Lainchaur, Kathmandu, Nepal \\ ${ }^{2}$ Central Department of Geology, Tribhuvan University, Kirtipur, Kathmandu, Nepal \\ *Corresponding author: sunitabhtry.828@gmail.com
}

\begin{abstract}
Because of the occurrence of various rock types within the short span of areas, the Malekhu Khola area is one of the most promising areas where scope of stones is high. This paper presents recognition of the most promising rock types in terms of their geology and discontinuity for evaluating suitability for building stones. The research focuses on the assessment of nine different rock types allocated along the Malekhu Khola, central Nepal. Geological parameters, rock mass characterization and discontinuity analysis were carried out in each of allocated sites. During field study, rock masses were categorised based on different geological parameters, and on number of joint set, tentative block shape, size and volume. Field-based data were tabulated, analysed, and finally identified for the block size and geometry, and rock mass quality for stones. The number of major joint set ranges from one to four with random joint sets. The study shows that the outcrop condition of rock is faintly to slightly weathered and strongly indurated. The study shows that the rock types depending on the Rock Mass Rating (RMR) system vary from poor to very good. The block types that could be extracted are flat, long and compact. The probable end uses of these rock types could be armourstone, interior and exterior paving, cladding and foundation.
\end{abstract}

Keywords: Natural stones, Joint volume, Discontinuity analysis, Geological attribute, Malekhu River

Paper Received: 31 Jan 2018

Paper Accepted: 17 March 2018

\section{INTRODUCTION}

Natural stones are naturally occurring rock types used for various purposes such as walling, paving, or roofing materials in construction after different procedure of cutting or shaping. The use and demand of natural stones for various engineering purposes have been increased with urbanization in the remote areas of Nepal. Various studies have been carried out for the recognition of various rock types for dimension stones in Nepal (Ghimire and Napit, 2008; Shrestha and Napit, 2003; Singh and Tamrakar, 2013). However, the study of the most promising and prospective rock types is still lacking. Currently, a number of methods are being used for the assessment of discontinuity analysis (Palmström, 2001; Wang et al., 2003; Smith, 2004). In reference to research problem, this study is a kind of support to explore the rock types and their characteristics based on discontinuity analysis and geological attributes.

The study area belongs to the part of the Malekhu Khola watershed that is bounded by latitudes $27^{\circ} 44^{\prime} \mathrm{N}$ to $27^{\circ} 52^{\prime} \mathrm{N}$ and longitudes $84^{\circ} 48^{\prime} \mathrm{E}$ to $84^{\circ} 59^{\prime} \mathrm{E}$, respectively (Fig. 1). Stratigraphically, the study area lies within the Lesser Himalaya of central Nepal (Stöcklin and Bhattarai, 1980). The study area extends across the strike of the major formations, which comprise of various rock types such as limestone, quartzite, amphibolite, marble, metasandstone, augen gneiss, granite etc.
Because of occurrence of various rock types within the short span of areas, the Malekhu Khola area is one of the most promising areas where opportunity of stones is high. Preliminary field based study was used to assess the dimension, shape and size of rock mass. Most of the same rock types found within the same rock units along the Malekhu river corridor have varying characteristics because of their varying rock mass characteristics, mineralogical composition etc. which ultimately affects their suitability in engineering purposes.

Rock mass condition helps to know about the condition of rock, number of joint sets, persistency and their joint condition (Bieniawski, 1973). Joint set signifies the actual block shape for extraction (Elci and Tuck, 2014). Discontinuity analysis develops an idea on providing block volume, block size and finally helps to identify the economic zones for quarrying (Palmström, 1995). The block volume is an important parameter to estimate resource and enhance economical production for larger industries. Geology, rock mass characteristics and discontinuities help to identify and evaluate rock mass for probable engineering applications. Therefore, the objectives of the research were to explore rock types, their characteristics based on field-based geological assessment and discontinuity, and finally differentiate and evaluate rocks suitable for various engineering applications. 


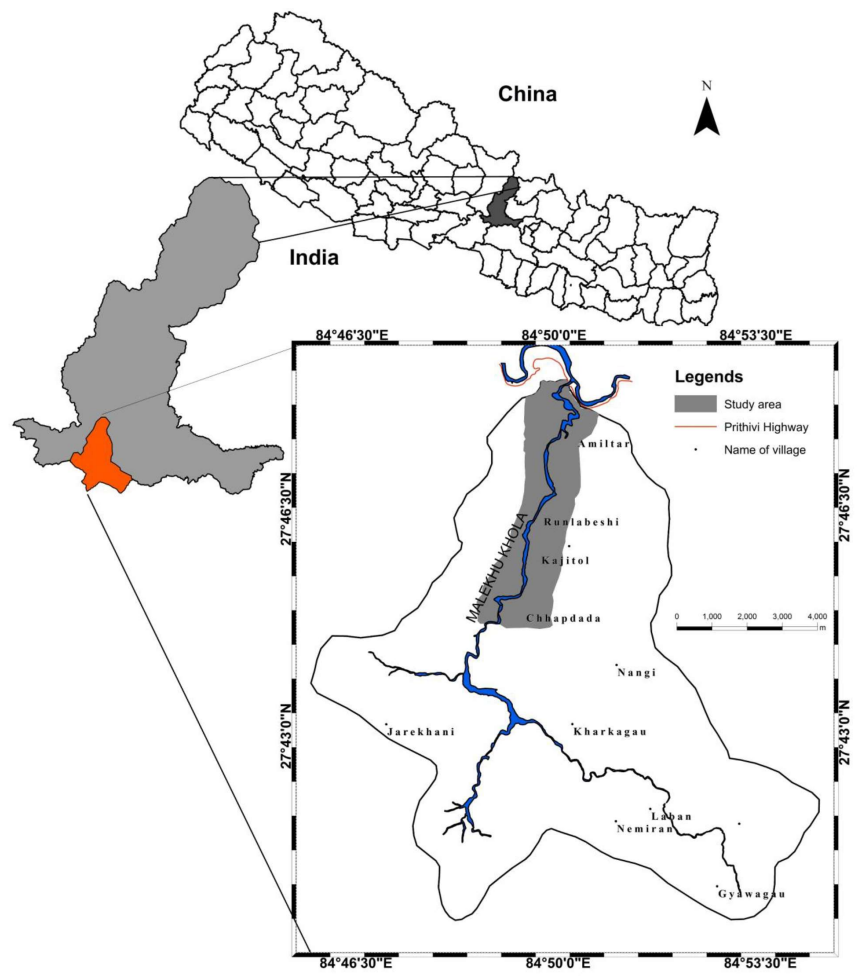

Fig. 1: Location map of the study area

\section{METHODOLOGY}

Reconnaissance survey was carried out using 1:25,000 scale maps traversing along the river corridor, gravel roads and trails. Nine locations were assigned for the field investigation depending on their probable rock types, outcrop extension and condition, topography, morphology, outcrop extension, rock quality and characteristics, socio-environmental consideration, etc. Geological attributes, geotechnical properties and discontinuity analysis are three indispensable properties that help to find the suitability of rock sample for engineering applications. Geological attributes focus on promising rock type, large vertical and lateral extension of rock mass, stratigraphical position in the Lesser Himalayan rock unit, whereas geotechnical studies help to find out the tentative rock mass quality, strength of rock mass and their characteristics. Finally, discontinuity analysis focuses on amount of block volume, block shape and size that could be extracted in a specified rock exposure. The attributes assessed during this studies were as below:

1. Geological attributes: Geological parameters mainly included outcrop, morphology, topography, dimension, structure, metamorphic grade, stratigraphy and lithology. Physical properties, texture, minor structures and even geographic situation determine the suitability of rock formation to exploitation.

2. Geotechnical studies: Rock mass rating (RMR) system was measured in accordance to Bieniawski (1989). Strength of intact rock, Rock Quality Designation (RQD), spacing of discontinuities, joint condition and groundwater condition were measured to calculate the Rock Mass Rating (RMR) system.
Strength of intact rock was determined by hammering the rock exposure and their strength in response to hammer was correlated to Brown (1891). Finally, the RMR class was found to be the addition of above five parameters i.e.

$$
\mathrm{RMR}=\mathrm{R} 1+\mathrm{R} 2+\mathrm{R} 3+\mathrm{R} 4+\mathrm{R} 5
$$

where, R1 is the rating for strength of intact rock (UCS), $\mathrm{R} 2$ is the rating for Rock Quality Designation (RQD), R3 is the rating for spacing of discontinuities, R4 is the rating for joint condition and R5 is the rating for groundwater condition.

RQD \% was found in reference to the Palmström (2005) as:

$$
\text { RQD }(\%)=110-3.5 \mathrm{~J}_{\mathrm{V}}
$$

Joint volume ( Jv) was calculated from average relation to joint frequency, where average joint frequency was determined from joint spacings measured perpendicular distance between two major joint sets, and using the following equation:

$$
\mathrm{J}_{\mathrm{V}}=1 / \mathrm{S}_{1}+1 / \mathrm{S}_{2}+1 / \mathrm{S}_{3}
$$

where, $\mathrm{S}_{1}$ : Maximum joint spacing, $\mathrm{S}_{2}$ : Intermediate joint spacing and $\mathrm{S}_{3}$ : Minimum joint spacing (Fig. 2).

3. Discontinuity analysis: The discontinuity analysis included joint spacing, joint frequency, joint density, joint volume, joint size, joint shape and block quality designation (BQD). The measurement and characterization of rock mass jointing was done in reference to Palmström (2005) which discusses on joint conditions of rock:- Joint roughness, Joint alteration, Joint size, and termination. Palmström (1995) assessed the block size (expressed as block volume, $\mathrm{V}_{\mathrm{b}}$ in $\mathrm{m}^{3}$ ) of the rock mass from the equation:

$$
\mathrm{V}_{\mathrm{b}}=\beta \times \mathrm{J}_{\mathrm{V}}-3
$$

where, $\beta$ is a block shape factor, which was determined in accordance with the jointing pattern (from Palmström, 1995, using the following relation:

$$
\left.\beta=\left(\alpha_{2}+\alpha_{2} \times \alpha_{3}+\alpha_{2}\right)^{3 /(}\left(\alpha_{2} \times \alpha_{3}\right)^{2}\right)
$$

where, $\alpha_{2}=S_{2} / S_{1}, \alpha_{3}=S_{3} / S_{1}$. For the assessment of the rock mass analysis, Block Quality Designation (BQD) was determined in accordance with Elci and Turk (2014) as follows:

$$
\mathrm{BQD} \%=(\mathrm{Ls} / \mathrm{L}) \times 100
$$

where, $\mathrm{Ls}=$ Sum total scanline length of joint sets more than $1 \mathrm{~m}$ ) and $\mathrm{L}=$ Total length of the scan line.

Finally, nine different sites were evaluated for probable end uses for engineering purposes based on their weathering grade, induration, BQD, Joint volume, Joint shape and Strength of intact rock. 

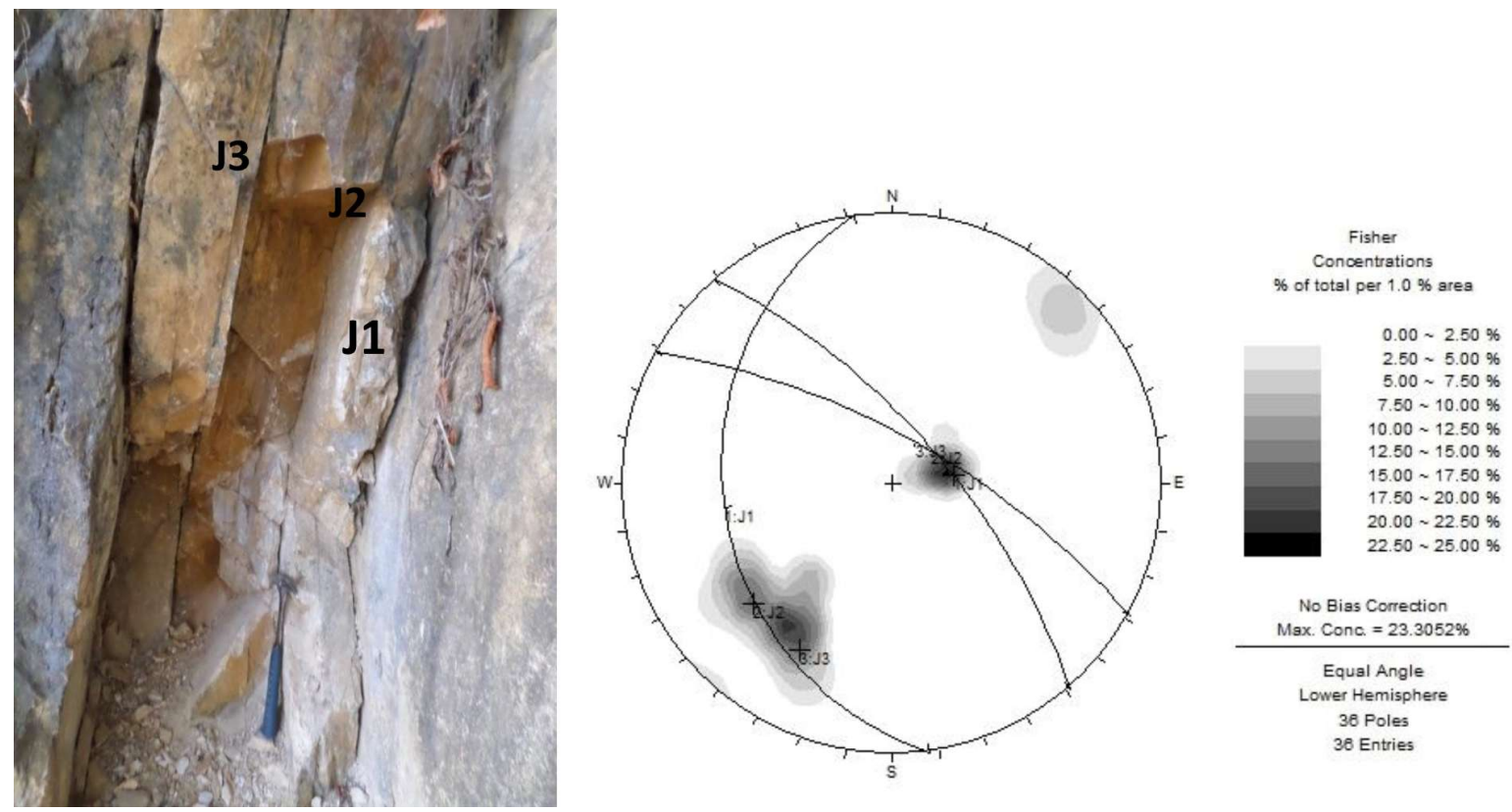

Fig. 2: Rock exposure showing their (a) major joint set (b) stereoplot of given sample (sample: BM-M1)

\section{GEOLOGICAL SETTING}

The stratigraphy of the study area is discussed under the Nawakot complex and the Kathmandu Complex as shown in Table 1 (Stöcklin and Bhattarai, 1977; Stöcklin, 1980). The Nawakot Complex comprises the Lower Nawakot Group and the Upper Nawakot Group (Precambrian age). The Kathmandu Complex is divided into the Bhimphedi Group (older-precambrian age) and the Phulchauki Group (younger Paleozoic age). The study area comprises the Upper Nawakot Group, the Bhimphedi Group and the Phulchauki Group (Tistung Formation) (Table 1, Fig. 3).

Table 1: Stratigraphic succession of Central Nepal (After Stöcklin and Bhattarai, 1997, and Stöcklin, 1980)

\begin{tabular}{|c|c|c|c|c|c|}
\hline & Unit & Formation & Main Lithology & $\begin{array}{c}\text { Apparent } \\
\text { Thickness (m) }\end{array}$ & Age \\
\hline \multirow{9}{*}{ 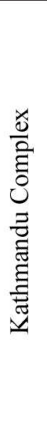 } & \multirow{5}{*}{ 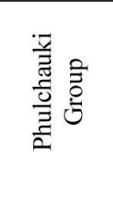 } & Godavari Limestone & Limestone, dolomite & 300 & Devonian \\
\hline & & Chitlang Formation & Slate & 1,000 & Silurian \\
\hline & & Chandagiri Limestone & Limestone & 2,000 & Cambro-Ordovician \\
\hline & & Sopyang Formation & Calc-phyllite, slate & 200 & Cambrian \\
\hline & & Tistung Formation & Metasandstone, phyllite & 3,000 & Late Precambrian \\
\hline & \multirow{4}{*}{ 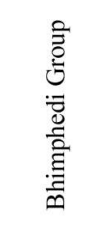 } & Kulikhani Formation & Quartzite, schist & 2,000 & Precambrian \\
\hline & & Chisapani Quartzite & White quartzite & 400 & Precambrian \\
\hline & & Kalitar Formation & Schist, quartzite & 2,000 & Precambrian \\
\hline & & Bhainsedobhan Marble & Marble & 800 & Precambrian \\
\hline \multirow{9}{*}{ 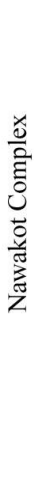 } & \multirow{3}{*}{ 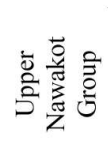 } & Robang Formation & $\begin{array}{l}\text { Mahabharat Thrust (MT) } \\
\text { Phyllite, quartzite }\end{array}$ & $200-1,000$ & Paleozoic \\
\hline & & Malekhu Limestone & Limestone, Dolomite & 800 & Paleozoic \\
\hline & & Benighat Slate & Slate, argillaceous dolomite & $500-3,000$ & Paleozoic \\
\hline & \multirow{6}{*}{ 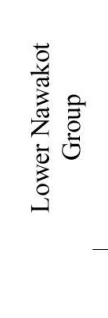 } & Dhading Dolomite & $\begin{array}{l}\text { Unconformity (?) } \\
\text { Stromatolitic dolomite }\end{array}$ & $500-1,000$ & Late Precambrian \\
\hline & & Nourpul Formation & Phyllite, quartzite, dolomite & 800 & Late Precambrian \\
\hline & & Dandagaon Phyllite & Phyllite & 1,000 & Late Precambrian \\
\hline & & Fagfog Quartzite & White quartzite & 400 & Late Precambrian \\
\hline & & Kuncha Formation & $\begin{array}{c}\text { Phyllite, quartzite, Conglomerate, } \\
\text { gritstone }\end{array}$ & 5,000 & Late Precambrian \\
\hline & & alik Group & $\begin{array}{c}\text { Main Boundary Thrust (MBT) } \\
\text { Conglomerate, sandstone, } \\
\text { mudstone. }\end{array}$ & $\begin{array}{c}\text { Several } \\
\text { Kilometers }\end{array}$ & Neogene \\
\hline
\end{tabular}




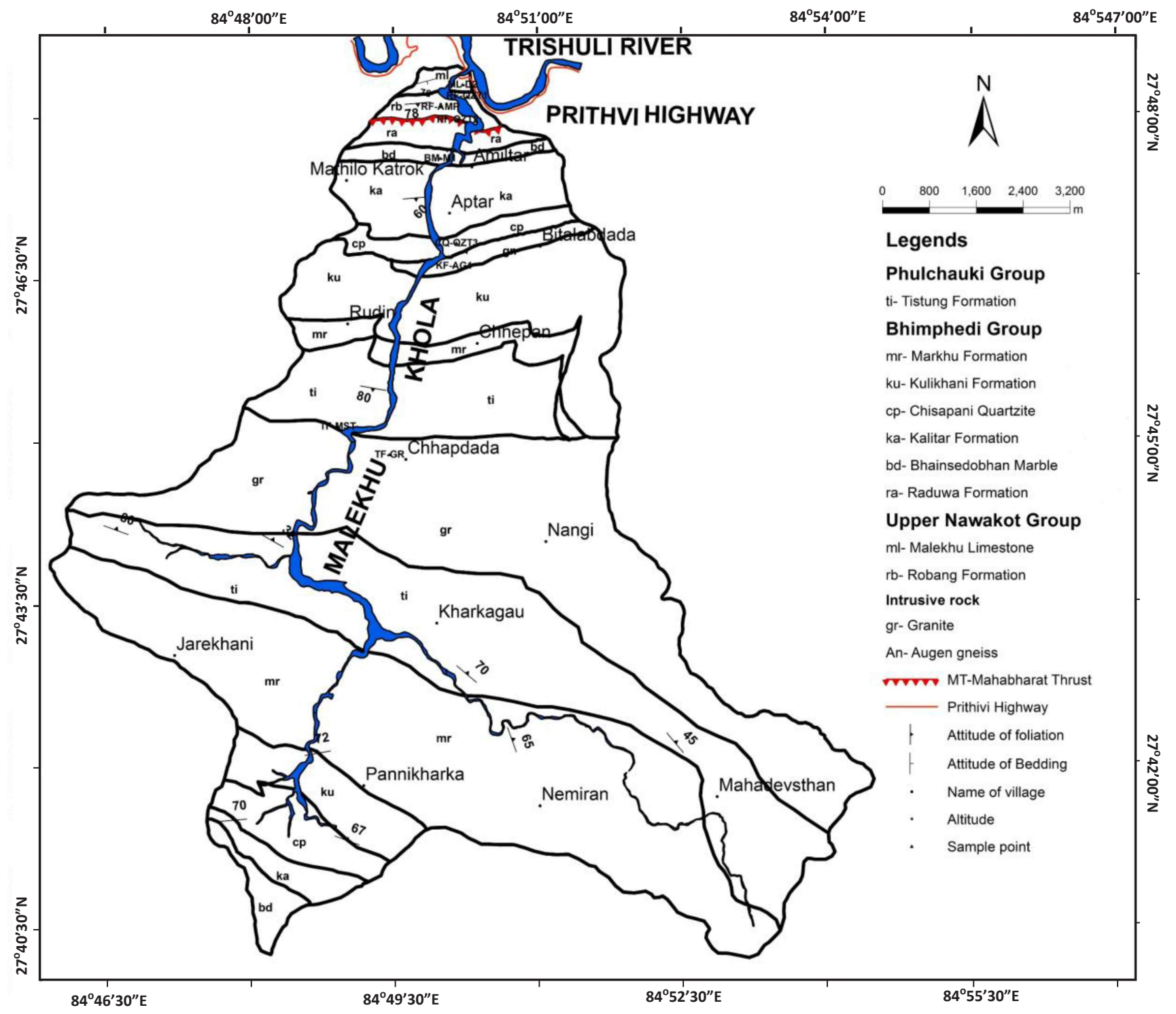

Fig. 3: Geological map of the study area (Stöcklin and Bhattarai, 1977 and Stöcklin, 1980)

The granitic intrusion exists at the middle stretch of the Malekhu Khola that comprises south dipping northern limb. The upstream stretch comprises of north dipping southern limb indicating the core of the Mahabharat Syncline.

\section{RESULTS}

Nine different desirable sites were categorized into three classes based on their rock types, lithology and compositions.

1.Finely crystalline argillaceous dolomite (ML-D2),

2. Foliated, medium to coarsely crystalline, white to light grey quartzite (RF-QZT1, RF-QZT2 \& CQ-QZT3), massive, coarsely crystalline white marble (BM-M1) and coarsely crystalline and dark grey augen gneiss (KF-AG1), and

3.Foliated, medium crystalline and green amphibolite (RF-AMP) and massive, coarsely crystalline granite (TF-GR).

\section{Geological attributes}

The limestone (ML-D2) of the Malekhu Limestone has dark grey to bluish grey, finely crystalline, argillaceous parting, laminated, intercalation of crenulated phyllite with quartz vein in few portions. Quartzite samples of the Robang Formation (RF-QZT1 and RF-QZT2) has light grey to dark grey, fine to medium grained, crystalline and laminated (Figs. 4a and b). But quartzite of the Chisapani Quartzite is dark grey medium to coarsely crystalline (Fig. 4c). The marble rock mass of the 

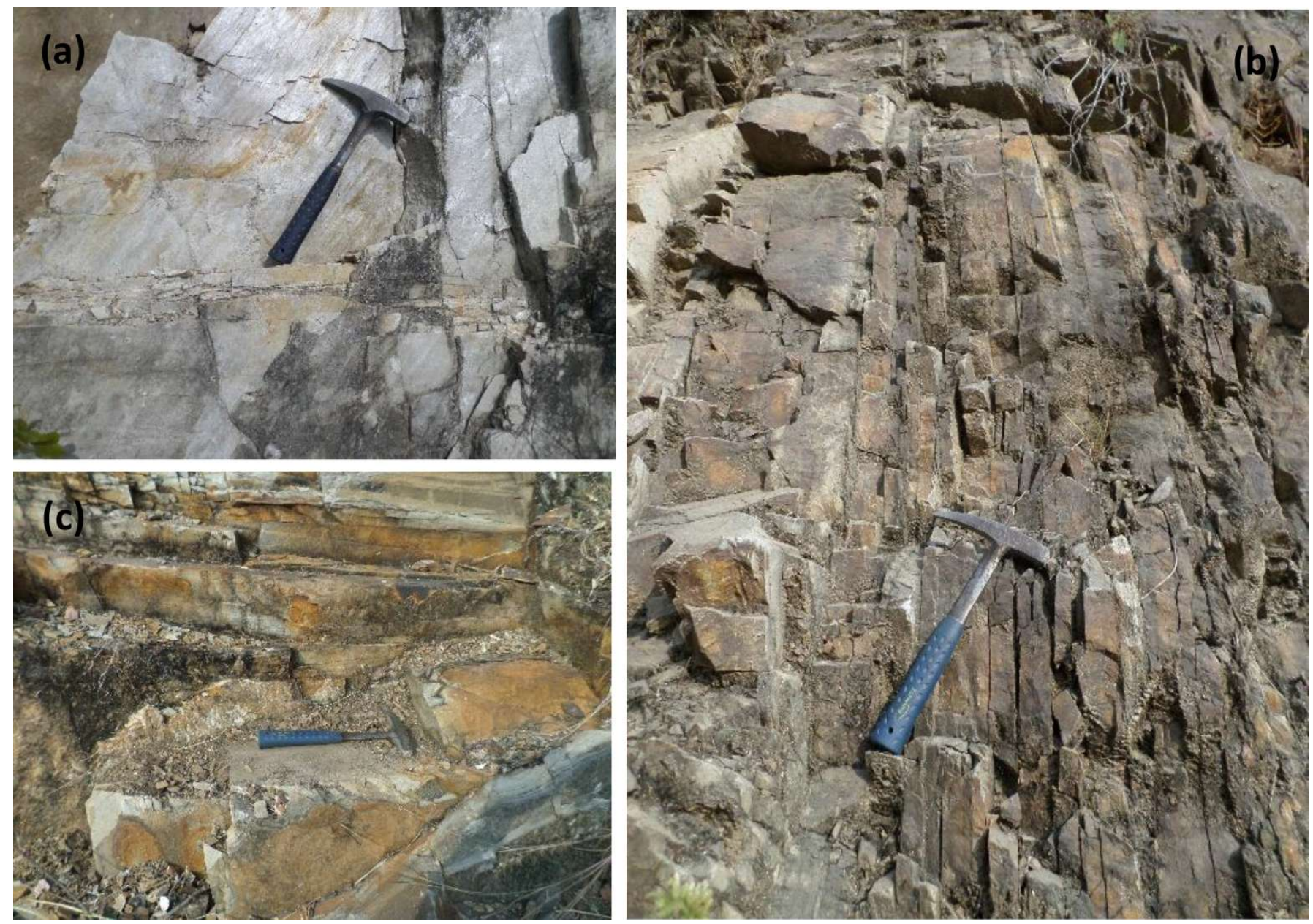

Fig. 4: Dark grey to grey quartzite samples: (a) Serricite quartzite, RF-QZT1, (b) Quartzite RF-QZT2, and (c) Dark grey medium-grained quartzite CQ-QZT3

Bhainsedobhan Marble (BM-M1) has white, fine to medium crystalline texture. The Augen gneiss rock mass of the Kulikhani Formation (KF-AG1) is dark grey coarsely crystalline texture. The metasandstone is dark grey and granite of the Tistung Formation (TF-GR) has coarse crystalline textue. All the sample sites contain well developed foliation having three to four major joint sets with varying random joint sets. Besides rock of granite, all the samples have medium grade of metamorphism. Weathering condition and induration range from slightly to moderately weathered and strongly to very strongly indurated, respectively.

Most of the sites have precipitous topography with $65^{0}$ hillslope angle while the site TF-MST on the left bank of the Malekhu Khola has steep hill slope $\left(45^{\circ}\right)$. The site of quartzite of the Robang Formation has a cliffed hillslope that falls under $85^{0}$. The outcrop dimension is the largest in granite with $300 \times 100$ $\mathrm{m}^{2}$ and smallest in quartzite of the Robang Formation (Dhunga Quartzite member: RF-QZT2) with $80 \times 30 \mathrm{~m}^{2}$. The extension of the rock exposure is found to be continuous and extends laterally and vertically by more than $100 \mathrm{~m}$.

\section{Geotechnical studies}

RMR system proposed by Bieniawski, 1989 shows rock sample falls between fair to very good rock, the quartzite of the Robang Formation being fair and the augen gneiss of the Kulikhani Formation falls under very good (Table 3). Rest of the sample falls under good rock type. For the quality of block extraction, the Block Quality Designation (BQD) value ranges from very poor to good type (Table 3). Very good rock types are of dolomite, quartzite (ML-D2, RF-QZT1 \& RF-QZT2) and good rock types are of augen gneiss and amphibolite (KFAG1 \& RF-AMP).

\section{Discontinuity analysis}

Average joint frequency of rock varies from 4.28 to 30.39. The block volume that could be extracted from nine different sample sites ranges from 0.1 to $12.68 \mathrm{~m}^{3}$. The block shape factor $\beta$ ranges from nine different rock types ranges from 21.66 to $124.81 \mathrm{~m}^{3}$ (Table 4). Tentative block shape was determined based on Palmström (1995) where samples ML-D2 
Table 2: Overall geological attributes of nine different sites

\begin{tabular}{|c|c|c|c|c|c|c|c|c|c|}
\hline Sample no & ML-D2 & RF-QZT1 & RF-AMP & RF-QZT2 & BM-M1 & CQ-QZT3 & KF-AG1 & TF-MST & TF-GR \\
\hline Topography & \multicolumn{3}{|c|}{ Precipitous hill slope, $65^{\circ}$} & $\begin{array}{l}\text { Cliffed hill } \\
\text { slope, } 85^{\circ}\end{array}$ & \multicolumn{3}{|c|}{ Precipitous hill slope, $65^{\circ}$} & $\begin{array}{l}\text { Steep hill } \\
\text { slope, } 45^{\circ}\end{array}$ & $\begin{array}{l}\text { Precipitous } \\
\text { hill slope, } \\
65^{\circ}\end{array}$ \\
\hline $\begin{array}{l}\text { Outcrop } \\
\text { dimension }\left(\mathrm{m}^{2}\right)\end{array}$ & $22.5 * 12.5$ & $75 * 42.5$ & $32.5 * 17.5$ & $80 * 30$ & \multirow{2}{*}{$\begin{array}{l}12.5 * 9.5 \\
\text { Bhainsedobhan } \\
\text { marble }\end{array}$} & \multirow{2}{*}{$\begin{array}{l}45.5 * 17.5 \\
\text { Chisapani } \\
\text { quartzite }\end{array}$} & \multirow{2}{*}{$\begin{array}{l}67.5 * 15.5 \\
\text { Kulikhani } \\
\text { formation }\end{array}$} & $45.5 * 12.5$ & $300 * 100$ \\
\hline Stratigraphy & $\begin{array}{l}\text { Malekhu } \\
\text { limestone }\end{array}$ & Robang fo & nation & & & & & \multicolumn{2}{|c|}{ Tistung formation } \\
\hline Morphology & \multicolumn{9}{|c|}{ Continuous, more than $100 \mathrm{~m}$ lateral and vertical extension } \\
\hline $\begin{array}{l}\text { Structure } \\
\text { Metamorphic } \\
\text { grade }\end{array}$ & $\begin{array}{l}\text { Foliation, } \\
\text { Medium g1 }\end{array}$ & $\begin{array}{l}\text { set joint } \\
\text { de }\end{array}$ & $\begin{array}{l}\text { Foliation, } \\
3 \text { set joint }\end{array}$ & $\begin{array}{l}\text { Foliation, } \\
4 \text { set joint, }\end{array}$ & $\begin{array}{l}\text { Foliation, } 3 \text { set } \\
\text { joint, }\end{array}$ & $\begin{array}{l}\text { Foliation, } \\
4 \text { set joint }\end{array}$ & $\begin{array}{l}\text { Foliation, } \\
3 \text { set joint, }\end{array}$ & $\begin{array}{l}\text { Random } \\
\text { joint, }\end{array}$ & $\begin{array}{l}\text { Foliation, } \\
3 \text { set joint, } \\
\text { Medium } \\
\text { grade }\end{array}$ \\
\hline Lithology & Dolomite, & hite, fine, c & stalline & $\begin{array}{l}\text { Quartzite, } \\
\text { dark grey, } \\
\text { fine- } \\
\text { medium, } \\
\text { crystalline. }\end{array}$ & $\begin{array}{l}\text { Marble, white, } \\
\text { fine - medium, } \\
\text { crystalline. }\end{array}$ & $\begin{array}{l}\text { Quartzite, } \\
\text { dark } \\
\text { grey, } \\
\text { coarse, } \\
\text { crystalline }\end{array}$ & $\begin{array}{l}\text { Augen } \\
\text { gneiss, } \\
\text { dark grey, } \\
\text { crystalline, } \\
\text { coarse. }\end{array}$ & $\begin{array}{l}\text { Granite, } \\
\text { dark grey, } \\
\text { coarse, } \\
\text { crystalline }\end{array}$ & $\begin{array}{l}\text { Metasand- } \\
\text { stone, dark } \\
\text { grey, fine- } \\
\text { medium. }\end{array}$ \\
\hline $\begin{array}{l}\text { Weathering } \\
\text { grade }\end{array}$ & $\mathrm{IB}$ & & & II & II & IB & IB-II & II & II \\
\hline Induration & $\mathrm{H} 4-\mathrm{H} 5$ & & & $\mathrm{H} 4$ & H5 & $\mathrm{H} 4$ & $\mathrm{H} 4$ & $\mathrm{H} 4-\mathrm{H} 5$ & H4-H5 \\
\hline
\end{tabular}

Table 3: Rock mass rating category of the studied sample

\begin{tabular}{llllllll}
\hline \multirow{2}{*}{ Sample no } & \multicolumn{9}{l}{ Rock Mass Rating parameters } & & RMR category \\
\cline { 2 - 5 } & R1 & R2 & R3 & R4 & R5 & RMR value & \\
\hline ML-D2 & 7 & 17 & 9 & 20 & 15 & 68 & Good rock \\
RF-QZT1 & 12 & 8 & 12 & 20 & 15 & 67 & Good rock \\
RF-AMP & 15 & 17 & 13 & 14 & 15 & 74 & Good rock \\
RF-QZT2 & 12 & 3 & 9 & 17 & 15 & 56 & Fair rock \\
BM-M1 & 12 & 20 & 14 & 13 & 15 & 74 & Good rock \\
CQ-QZT3 & 15 & 13 & 12 & 17 & 15 & 72 & Good rock \\
KF-AG1 & 12 & 20 & 18 & 16 & 15 & 81 & Very good rock \\
TF-GR & 12 & 20 & 13 & 8 & 15 & 60 & Fair rock \\
TF-MST & 12 & 20 & 13 & 20 & 7 & 74 & Good rock \\
\hline *R1, Unconfined Compressive Strength (UCS); R2, Rock Quality Designation (RQD); R3, Joint condition;
\end{tabular}

R4, Joint roughness; R5, Groundwater Conditions

Table 4: Table showing discontinuity analysis of the study sites

\begin{tabular}{|c|c|c|c|c|c|c|c|c|c|c|}
\hline Sample no & & $\begin{array}{l}\text { ML- } \\
\text { D2 }\end{array}$ & $\begin{array}{l}\text { RF- } \\
\text { QZT1 }\end{array}$ & RF-AMP & RF-QZT2 & $\begin{array}{l}\text { BM- } \\
\text { M1 }\end{array}$ & $\begin{array}{l}\text { CQ- } \\
\text { QZT3 }\end{array}$ & $\mathrm{KF}-\mathrm{AG} 1$ & TF-GR & TF-MST \\
\hline \multirow[t]{2}{*}{$\begin{array}{l}\text { JOINT } \\
\text { DENSITY }\end{array}$} & $\begin{array}{l}\text { Total } \\
\text { freq. }\end{array}$ & $\begin{array}{l}8.9- \\
27.74\end{array}$ & $\begin{array}{l}3.45- \\
58.34\end{array}$ & $\begin{array}{l}1.39- \\
20.20\end{array}$ & $\begin{array}{l}3.25- \\
75.35\end{array}$ & $\begin{array}{l}3.33- \\
24.30\end{array}$ & $\begin{array}{l}4.33- \\
28.36\end{array}$ & $1.08-5.70$ & $\begin{array}{l}2.28- \\
12.0\end{array}$ & $\begin{array}{l}1.60- \\
18.10\end{array}$ \\
\hline & $\begin{array}{l}\text { Av } \\
. \text { Freq } \\
(\mathrm{Jv})\end{array}$ & 18.3 & 30.4 & 11 & 36.94 & 13.82 & 16.33 & 4.28 & 7.7 & 10.54 \\
\hline \multicolumn{2}{|c|}{ Block size $\left(\mathrm{V}_{\mathrm{b}}, \mathrm{m}^{3}\right)$} & 5.67 & 0.56 & 4.1 & 0.8 & 1.26 & 0.1 & 12.68 & 2.3 & 0.23 \\
\hline \multirow{2}{*}{\multicolumn{2}{|c|}{$\begin{array}{l}\text { Block shape factor } \\
(\beta) \\
\text { Block type }\end{array}$}} & 217 & 36.8 & 27 & 28.33 & 75.21 & 123.8 & 28.79 & 39 & 31.86 \\
\hline & & $\begin{array}{l}\text { Long } \\
\text { and } \\
\text { flat }\end{array}$ & Flat & Compact & Compact & Flat & Long & Compact & Flat & Compact \\
\hline
\end{tabular}




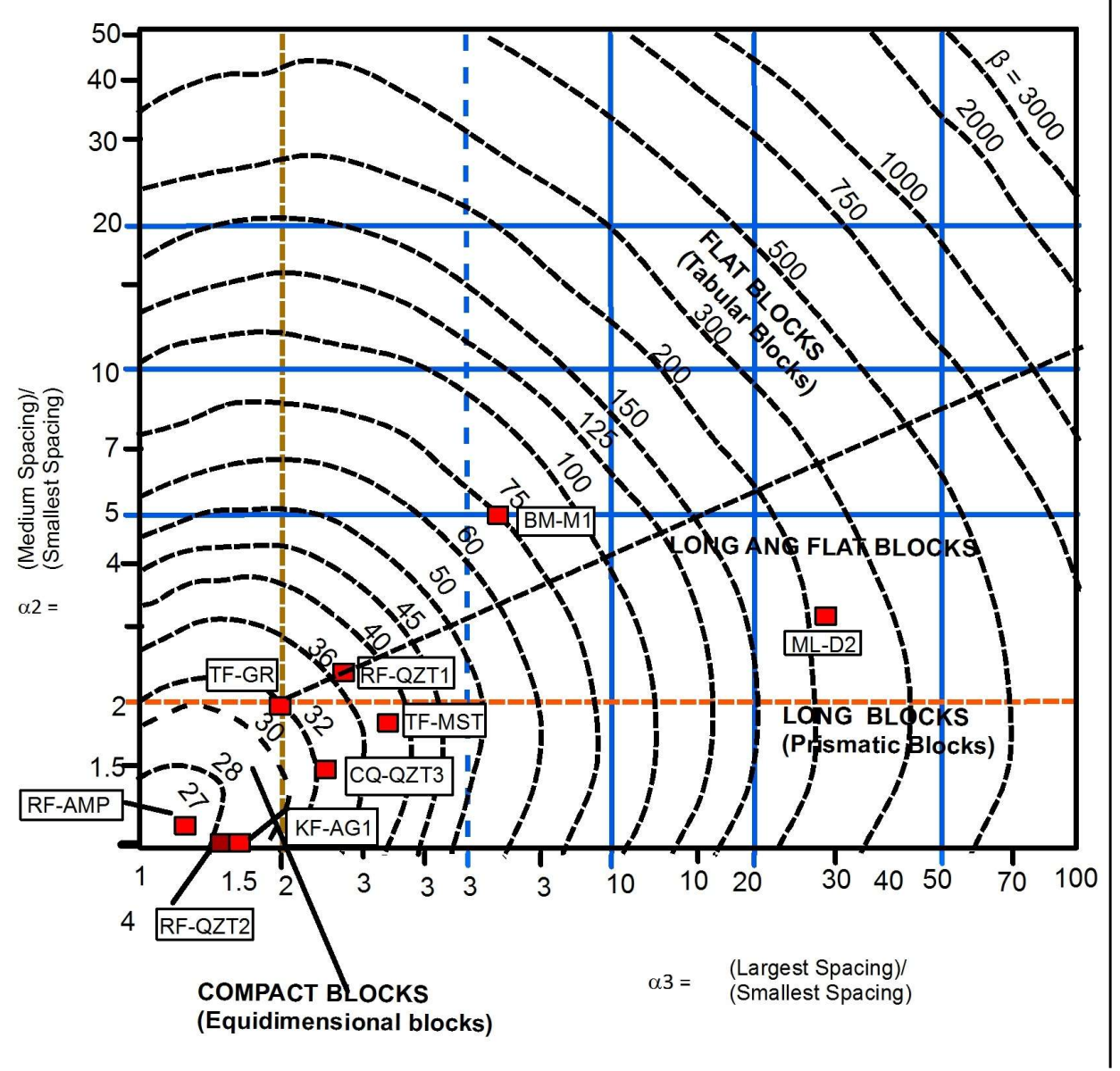

Fig. 5: Block types characterized by the block shape factor of the studied samples

Table 5: Summarized table for interpretation (Armourstone)

\begin{tabular}{|c|c|c|c|c|c|c|c|c|c|}
\hline Sample & $\begin{array}{l}\text { ML- } \\
\text { D2 }\end{array}$ & RF-QZT1 & RF-AMP & RF-QZT2 & $\begin{array}{l}\text { BM- } \\
\text { M1 }\end{array}$ & $\begin{array}{l}\text { CQ- } \\
\text { QZT3 }\end{array}$ & $\begin{array}{l}\text { KF- } \\
\text { AG1 }\end{array}$ & TF-GR & $\begin{array}{l}\text { TF- } \\
\text { MST }\end{array}$ \\
\hline Lithology & $\begin{array}{l}\text { Dolom } \\
\text { ite }\end{array}$ & Quartzite & Amphibolite & Quartzite & Marble & Quartzite & $\begin{array}{l}\text { Augen } \\
\text { gneiss }\end{array}$ & Granite & $\begin{array}{l}\text { Metasa- } \\
\text { ndstone }\end{array}$ \\
\hline BQD category & Poor & $\begin{array}{l}\text { Very } \\
\text { Poor }\end{array}$ & Good & $\begin{array}{l}\text { Very } \\
\text { Poor }\end{array}$ & Poor & $\begin{array}{l}\text { Very } \\
\text { Poor }\end{array}$ & Good & Poor & Fair \\
\hline $\begin{array}{l}\text { Volumetric } \\
\text { Joint }\end{array}$ & 18.3 & 30.4 & 11.4 & 36.9 & 13.8 & 16.33 & 4.3 & 7.7 & 10.54 \\
\hline volume $(\mathrm{Jv}) \mathrm{m}^{3}$ & SB & VSB & SB & VSB & SB & SB & $\mathrm{MB}$ & MB & MB \\
\hline \multirow[t]{2}{*}{ UCS, Mpa } & $50-100$ & $100-250$ & $>250$ & $100-250$ & $\begin{array}{l}100- \\
250\end{array}$ & $>250$ & $\begin{array}{l}100- \\
250\end{array}$ & $\begin{array}{l}100- \\
250\end{array}$ & $100-250$ \\
\hline & M & G-E & $\mathrm{E}$ & G-E & G-E & $\mathrm{E}$ & G-E & G-E & G-E \\
\hline $\begin{array}{l}\text { Evaluation for } \\
\text { armourstone }\end{array}$ & M & M & G & M & G & G & $\mathrm{G}$ & G & $\mathrm{G}$ \\
\hline
\end{tabular}


has long and flat blocks, RF-AMP and KF-AG1 have compact blocks, RF-QZT1, TF-GR and BM-M1 have flat blocks, and the other samples have long block shape (Fig. 5).

Volumetric joint count $\left(\mathrm{J}_{\mathrm{v}}\right)$ ranges from $4.3 \mathrm{~m}^{3}$ (moderate blocks) to $36.9 \mathrm{~m}^{3}$ (very small blocks) in accordance with ISRM (1978) and Toyos et al. (1994). BQD ranges from very poor in quartzite samples to good in amphibolite and augen gneiss, respectively.

\section{EVALUATION OF STONES FOR VARIOUS ENGINEERING APPLICATIONS}

Nine different sites were evaluated for armourstone and stone masonry based on their rock mass characteristics, discontinuity properties and unconfined compressive strength. Rock types analysed for evaluation were dolomite, sericite quartzite, amphibolite, marble, quartzite, augen gneiss, granite, metasandstone etc. Weathering grade and induration range from faintly to slightly weathered and strongly to very strongly indurated, respectively. These can be used for both armourstone and stone masonry.

\section{Armourstone}

Quartzite (RF-QZT1 and RF-QZT2) of the Robang Formation can be used moderately for armourstone because of very poor $\mathrm{BQD}$, very small block shape and strength value that ranges from 100-250 MPa. Another quartzite sample (CQQZT3) has similar properties with two other quartzite samples but have higher strength value, which indicates that this rock type can be used for armourstone. Dolomite and amphibolite have similar properties having poor BQD and small block shape but amphibolite has higher strength value compared to the former two rock types and indicates that amphibolite can be used for armourstone (Table 5). Granite sample being poor in $\mathrm{BQD} \%$ value, it has moderate block shape with wide range of strength values, and therefore can be used for armourstone. Being fair in rock type, moderate block size and wide range of UCS value, metasandstone can be used for armourstone (Table 5).

\section{Random rubble masonry}

Considering UCS values, all samples except metasandstone (TF-MST) have excellent UCS values in accordance with CPWD (2009) (Table 6). Being very small in block shape, very poor in BQD and having a wider range of strength value, quartzite samples of the Robang Formations are moderately suitable for stone masonry. While other quartzite sample CQ-QZT3 of the Chisapani Quartzite can be used for stone masonry because of its higher strength value. Dolomite and marble have poor BQD and small block shape indicating their usefulness for stone masonry due to higher strength values. Both the samples amphibolite and augen gneiss have excellent UCS values and good BQD. Among these rock types, amphibolite can be used moderately for stone masonry and augen gneiss is good enough to use because of its small and moderate block shape. Granite and metasandstone can be used for stone masonry because of their excellent UCS value and moderate block shape.

\section{DISCUSSIONS}

Quartzite samples of the Robang Formation (RF-QZT1 and RF-QZT2) and of the Chisapani Quartzite (CQ-QZT3) have more or less similar mineralogical composition but they have varying strength values due to their textural characteristics (Kheirelseed et al., 2008; Bista and Tamrakar, 2015). RF-QZT1 and RF-QZT2 differ in textural properties but these samples have same strength range due to presence of sericite minerals in RF-QZT1. Sample KF-AG1 and TF-GR require blasting during excavation because of massive structure, few joint sets with large persistency, high BQD \%, high strength value and low weathering grade. Agra granite of the Malekhu Khola and Ipa granite of the Makawanpur (Ghimire and Dhakal, 2007) are comparable to each other based on their strength value. Weathering grade ranges from slightly to moderately weathered indicating rock types slightly altered but not decomposed into clay minerals (Geological Society of London, 1977). Induration of most of the rock types ranges from strongly to very strongly indurated which indicates that rock types are stiff enough and have strong strength (Larsen et al., 1995). Most of the samples

Table 6: Summarized table for interpretation (Random Rubble Masonry)

\begin{tabular}{|c|c|c|c|c|c|c|c|c|c|}
\hline Sample & ML-D2 & RF-QZT1 & RF-AMP & RF-QZT2 & BM-M1 & CQ-QZT3 & KF-AG1 & TF-GR & TF-MST \\
\hline Lithology & Dolomite & Quartzite & Amphibolite & Quartzite & Marble & Quartzite & $\begin{array}{l}\text { Augen } \\
\text { gneiss }\end{array}$ & Granite & Metasandstone \\
\hline BQD category & Poor & Very Poor & Good & $\begin{array}{l}\text { Very } \\
\text { Poor }\end{array}$ & Poor & Very Poor & Good & Poor & Fair \\
\hline Volumetric & 18.3 & 30.39 & 11 & 36.94 & 14 & 16.3 & 4.28 & 8 & 11 \\
\hline $\begin{array}{l}\text { Joint volume } \\
(\mathrm{Jv})\end{array}$ & SB & VSB & SB & VSB & SB & SB & MB & MB & MB \\
\hline \multirow[t]{2}{*}{ UCS, Mpa } & $50-100$ & $100-250$ & $>250$ & $100-250$ & $100-250$ & $>250$ & $100-250$ & $100-250$ & $100-250$ \\
\hline & $\mathrm{E}$ & $\mathrm{E}$ & $\mathrm{E}$ & $\mathrm{E}$ & $\mathrm{E}$ & $\mathrm{E}$ & $\mathrm{E}$ & E & G-E \\
\hline $\begin{array}{l}\text { Evaluation for } \\
\text { stone masonry }\end{array}$ & G & M & G & M & G & G & E & G & E \\
\hline
\end{tabular}

** 98 Mpa granite; 20 Mpa Limestone; 80 Mpa Quartzite; 50 Mpa Marble (CPWD, 2009) 
except quartzite samples of the Robang Formation show high RQD values correspond to good to very good rock types. Augen gneiss, granite and amphibolite can be used for economical production for quarries. These rock sites are considered as suitable. The use of rock types may vary with the implication of their uses in field of building construction. Generally, the long and flat block can be used for slabbing and paving in outdoor use. The compact blocks can be used for foundation, retaining walls and stone masonry. The elongate blocks can be used as curb stones.

\section{CONCLUSIONS}

From the assessment of nine different rock types, the quality of rock masses was found to be fair to very good. From discontinuity analysis, BQD \% was found to be very poor to good (0-81\%). Block volume ranges from 21.789 (Malekhu limestone) to $123.81 \mathrm{~m}^{3}$ (Chisapani quartzite). Block shape was found to be long, flat and compact.

From the study, it can be concluded that the engineering applications for the same rock types can be different due to variation in the number of block size, weathering condition, block shape, induration, strength etc. Generally, dolomite, marble, augen gneiss, quartzite, metasandstone and granite can be used for both armourstone and random rubble masonry. Enduse for same rock type is influenced by discontinuity, quality, block shape and how it breaks. Generally, the long and flat block can be used for slabbing, paving in outdoor use. The compact blocks can be used as foundation, retaining walls and stone masonry.

\section{ACKNOWLEDGEMENT}

Authors are thankful to Chinese Academy of Science for providing financial support and Central Department of Geology for providing facilities of equipment. Authors are thankful to Mr. Prabin Tumbapo and Mr. Sushil Bhattarai for assisting during mapping and data collection.

\section{REFERENCES}

Bieniawski, Z.T., 1973, Engineering classification of jointed rock masses. Trans S. Afr. Inst. Civ. Engrs, v. 15, pp 335-344.

Bieniawski, Z. T., 1989, Engineering rock mass classifications. John Wiley \& Sons, New York, 251p.

Bista, K. and Tamrakar, N.K., 2015, Evaluation of strength and durability of rocks from Malekhu-Thopal Khola area, Central Nepal Lesser Himalaya for construction aggregates. Bull Dept Geol, Tribhuvan University, Nepal, v. 18, pp. 15-34. DOI: http://dx.doi.org/10.3126/bdg.v18i0.16454.

Brown, E.T., 1981, Putting the NATM in perspective. Tunnels and tunneling, v. 13, pp. 19-57.

CIRIR/CUR, 1991, Manual on the use of rock in coastal and shoreline engineering. Construction Industry Research and information Association, CIRIA special Publication 83/CUR Report, 154p.

CPWD, 2000, Specification. Government of India, Central Public Works Development, v.1, 523p.

Elci, H. and Tuck, N., 2014, Rock mass block quality designation for marble production, International Journal of Rock Mechanics and Mining sciences, v. 69, pp. 26-30.

Geological Society London, 1977, Engineering group working party report. The description of rock masses for Engineering Purpose. v. 10, pp. 355-388.

Ghimire J.R. and Dhakal P., 2007, Exploration of polished and dimension stones in some parts of Makawanpur and Lalitpur districts, Central Nepal, Department of mines and geology, government of Nepal, Kathmandu, Nepal, v. 4, 40p.

Ghimire, J.R. and Napit, D.K., 2008, Preliminary exploration of polished and dimension stones in some parts of Kavrepalanchowk districts, Central Nepal, Department of mines and geology, Government of Nepal, Kathmandu, Nepal, v. 5, pp. 22-270.

ISRM, 1978, suggested methods for the quantitative description in rock masses, International Journal of Rock Mechanics and mining science and geomechancis, vol. 15 (6), pp. 319-368.

Larsen, G. Federiksen, J. Villumsen, A. Federicia, J. Gravesen, P. Foged, N., Knudsen, B., and Baumann, J., 1995, A guide to engineering geological soil description. Denish Geotechnical Society, Bulletin, v. 1.

Palmström, A., 1995, RMi - a rock mass characterization system for rock engineering purposes. Ph.D. thesis, University of Oslo, Department of Geology, 400 p.

Palmström, A., 2005, Measurements of and Correlations between Block Size and Rock Quality Designation (RQD), Norconsult as, Norway Published in Tunnels and Underground Space Technology, v. 20, pp. 362-377.

Shrestha, U.B. and Napit, D.K., 2003, Dimension stone of Makawanpur District, Central Nepal, Journal of Nepal Geological Society, v. 28, pp 69-75.

Singh, J. L. and Tamrakar, N. K., 2013, Rock Mass Rating and Geological Strength Index of rock masses of ThopalMalekhu Khola areas, Central Nepal Lesser Himalaya, Bulletin of the Department of Geology, Tribhuvan University, Kathmandu, Nepal, v. 16, pp 29-42.

Smith, J.V., 2004, Determining the size and shape of blocks from linear Sampling for geotechnical rock mass classification and assessment. Journal of Structural Geology, v. 26, pp. 1317-39.

Stöcklin, J., 1980, Geology of Nepal and its regional Frame. Journal of the Geological Society of London, v. 137, pp. $1-34$. 
Stöcklin, J. and Bhattarai, K.D., 1977, Geology of the Kathmandu area and central Mahabharat range, Nepal Himalaya. Report of Department of Mines and Geology/ UNDP (unpublished), 64p.

Toyos, J.M., Taboada, J., Lambardeo, M., Romero, J.A., Menendez, A., 1994, Estudio de las discontinuities en yacimientos de roca ornamental. Boletim de Geologico y Minero, v. 105 (1), pp. 110-118.
Wang, L., Yamashita, F., Sugimoto, F., and Tan, G., 2003, A methodology for predicting the in situ size and shape distribution for rock blocks Rock Mech Rock Eng, v. 36, pp. 121-41. 